\title{
PENGEMBANGAN MODUL PRAKTIKUM TEKNIK DIGITAL MODEL ADDIE
}

\author{
Amirhud Dalimunthe ${ }^{1}$, Marwan Affandi², Eka Dodi Suryanto ${ }^{3}$ \\ 1,2,3 Fakultas Teknik Universitas Negeri Medan, \\ ${ }^{1}$ amirhud@unimed.ac.id, ${ }^{2}$ mr1.affandi@gmail.com , ${ }^{3}$ ekadodisuryanto@unimed.ac.id
}

\begin{abstract}
Abstrak: Masalah yang dihadapi saat melaksanakan praktikum Teknik Digital adalah modul praktikum yang tersedia belum belum sesuai dengan kompetensi lulusan. Masalah lainnya adalah beberapa modul yang membutuhkan perbaikan. Selain itu, panduan praktikum Teknik Digital juga belum lengkap. Solusi untuk permasalahan diatas salah satunya adalah mengembangkan modul praktikum Teknik Digital. Pengembangan modul praktikum Teknik Digital dilakukan dengan menggunakan pendekatan Project Based Learning. Model ADDIE diadaptasi dalam prosedur pengembangan modul praktikum dalam penelitian ini, yang terdiri dari Analysis, Design, Development, Implementation, dan Evaluation. Prosedur penelitian meliputi beberapa tahap yaitu analisis Potensi dan masalah, Pengumpulan data, Desain produk, Validasi desain, Revisi desain, Uji coba, Revisi produk, Uji coba pemakaian, Revisi produk dan Produksi. Hasil penelitian ini diharapkan dapat meningkatkan kompetensi, keterampilan, kreatifitas dan inovasi mahasiswa.
\end{abstract}

Kata Kunci: Pengembangan, Modul Praktikum, Teknik Digital, Model ADDIE.

\begin{abstract}
When attending digital engineering lectures and digital engineering internship courses, students often encounter difficulties because they need to have high logic skills when producing a series of works. Imperfect learning tools is one of the reasons for the above problems. However, some facilities and infrastructure do not support the practical and theoretical learning process. One of them is learning tools, especially practical modules that are not yet available. The purpose of this research is to develop a module and a Digital Engineering practicum jobsheet in accordance with the materials and competencies that students must achieve by utilizing the tools and materials available in the laboratory. The design of this research is $R \& D$. The product of this research will be validated by experts and tested on students after the product is revised. The development procedure adapted from the ADDIE model developed by Dick and Carry. The data analysis technique used a simple qualitative descriptive analysis technique. This research produces a practicum module that contains work procedures and job sheets. The results of the assessment obtained from 2 media experts were 89,4\% in the category of easy to understand, useful, interesting and worthy of being used as a practicum guide. The results of the assessment obtained from 2 media experts show that this module is valid and very good with an average value of 90,3\%. Students using this module gave an average rating of $89 \%$ for ease of learning, attractiveness, design and benefits.
\end{abstract}

Keywords: Development, Practicum Modul, Digital Engineering, ADDIE Model..

\section{PENDAHULUAN}

Perbaikan dan peningkatan kualitas pembelajaran terus dilakukan melalui penerapan strategi aplikatif serta membangun suasana interaktif dalam kegiatan belajar mengajar(Parmin, 2012; Degeng, 2013; Fry, H., Ketteridge, S., \& Marshall, 2014). Proses pembelajaran dapat didefinisikan sebagai suatu proses interaksi antara peserta didik, pendidik dan sumber belajar dalam satu lingkungan belajar(Suesthi Rahayuningsih, 2019).

Pembelajaran juga membutuhkan keseimbangan antara kompetensi hard skill dan soft skill(Fatkhurrohkhman et al., 2017). Tujuan utama proses pembelajaran bagi mahasiswa adalah membelajarkan mahasiswa supaya lebih aktif dalam mencari serta mengkontruksi pengetahuan agar dapat diterapkan dalam kehidupan sehari-hari untuk memecahkan masalah yang dihadapinya (Parmin, 2012). Selain itu, mahasiswa juga dapat mengembangkan ilmu yang diperolehnya untuk inovasi dan perkembangan teknologi lainnya.

Praktikum Teknik Digital merupakan salah satu mata kuliah wajib di program studi Teknik Elektro. Kesulitan yang umumnya dihadapi mahasiswa antara lain mahasiswa harus memiliki kemampuan logika yang tinggi dalam membuat suatu rangkaian. Permasalahan yang dihadapi oleh mahasiswa yaitu pada saat merancang, merakit dan uji coba 
(Fatkhurrohkhman et al., 2017). Selain mahasiswa, dosen juga menghadapi permasalahan pada proses pembelajaran praktikum Teknik Digital. Perangkat pembelajaran yang belum lengkap seperti modul praktikum, merupakan masalah utama yang sering terjadi. Selain itu, beberapa sarana dan prasarana yang kurang mendukung proses pembelajaran praktik juga menjadi masalah umum yang harus dihadapi.

Modul praktikum yang tersedia belum ditata dan dikoordinasikan dengan baik sesuai dengan kebutuhan kegiatan praktikum mahasiswa dan ada juga beberapa yang membutuhkan perbaikan. Selain itu, jobsheet untuk setiap modul praktikum juga belum lengkap, sehingga sulit untuk mengidentifikasi dan menyelaraskan antara kompetensi yang akan dicapai, materi pelajaran, modul yang digunakan dan learning outcome yang diharapkan.

Selain itu, permasalahan lain yang dihadapi yaitu proses pembelajaran masih menempatkan dosen sebagai pusat informasi. Dengan menggunakan pendekatan tersbut, kemampuan dosen dalam menyampaikan materi pembelajaran dan materi yang disampaikan menjadi patokan terhadap pemahaman yang diterima oleh mahasiswa. Hal ini akan mengakibatkan ilmu yang diperoleh mahasiswa merupakan ilmu pengetahuan yang hanya sekali lewat saja. Karena ilmu pengetahuan yang diterima tidak berasal dari pemahaman mereka sendiri sehingga akan cepat hilang dari ingatan. Proses pembelajaran yang berpusat pada dosen juga menyebabkan mahasiswa memiliki ketergantungan yang besar pada dosen. Misalnya pembelajaran memperbaiki kesalahan dalam merakit komponen dan rangkaian, sedangkan dosen tidak mampu untuk memantau seluruh pekerjaan mahasiswa di laboratorium (Fatkhurrohkhman et al., 2017).

Permasalahan yang dihadapi pada mata kuliah Teknik Digital oleh dosen dan mahasiswa dapat diatasi dengan pembelajaran kolaboratif yang menekankan pembelajaran pada mahasiswa dengan menyelaraskan kompetensi hardskill dan softskill mahasiswa. Pembelajaran kolaboratif menitikberatkan mahasiswa sebagai pusat kegiatan pembelajaran. Hal ini dapat mengurangi ketergantungan mahasiswa terhadap dosen, sehingga mahasiswa mampu mengerjakan dan mengevaluasi pekerjaan mereka secara mandiri. Mahasiswa juga diharapkan mampu untuk mencari, mengkontruksi dan mengembangkan pengetahuan yang diperoleh baik dari dosen maupun sumber belajar lainnya(Sumiati, 2009).

\section{METODE PENELITIAN}

Metode Penelitian yang diadaptasi pada penelitian adalah Research and Development (RnD). Pendekatan ini merupakan salah satu strategi atau metode dalam penelitian yang banyak diadaptasi untuk mengatasi masalah praktikum. Pendekatan Research and Development $(\mathrm{RnD})$ merupakan suatu proses atau langkah-langkah dalam kegiatan penelitian untuk mengembangkan suatu produk baru atau menyempurnakan produk yang telah ada dan dapat dipertanggungjawabkan. Produk tersebut dapat berupa perangkat keras ataupun perangkat lunak(Wagiran, 2013).

Model yang digunakan dalam penelitian ini adalah model prosedural. Model prosedural bersifat deskriptif dan lebih menekankan pada langkah-langkah pengembangan. Menurut teori Sugiyono, beberapa langkah yang harus dilakukan untuk menghasilkan suatu produk antara lain potensi dan masalah, pengumpulan data, desain produk, validasi desain, revisi desain produk, uji coba produk, revisi produk, uji coba pemakaian, revisi produk, dan produksi massal(Sugiyono, 2014)(Sugiyono, 2017).

Orientasi dari pendekatan Research and Development (RnD) ini yaitu menghasilkan produk berupa perangkat pembelajaran bagi mahasiswa. Perangkat pembelajaran yang dihasilkan dapat berupa Modul Praktikum dan Jobsheet Praktikum. Penelitian ini mengadaptasi model ADDIE beserta langkah-langkah pengembangan dikembangkan oleh Dick and Carry(Mulyatiningsih, 2012).

Rancangan penelitian ini diharapkan dapat menghasilkan atau mengembangkan suatu produk. Kemudian produk tersebut divalidasi oleh pakar dan diujikan kepada mahasiswa setelah produk direvisi. Prosedur Penelitian Research and Development (RnD)banyak dikemukkanan oleh para ahli. Salah satunya adalah prosedur penelitian Research and Development $(\mathrm{RnD})$ yang dikemukakan oleh 
Sugiyono(Sugiyono, 2014). Prosedur pelaksanaan penelitian Research and Development $(\mathrm{RnD})$ menurut Sugiyono dapat dilihat pada Gambar 1.

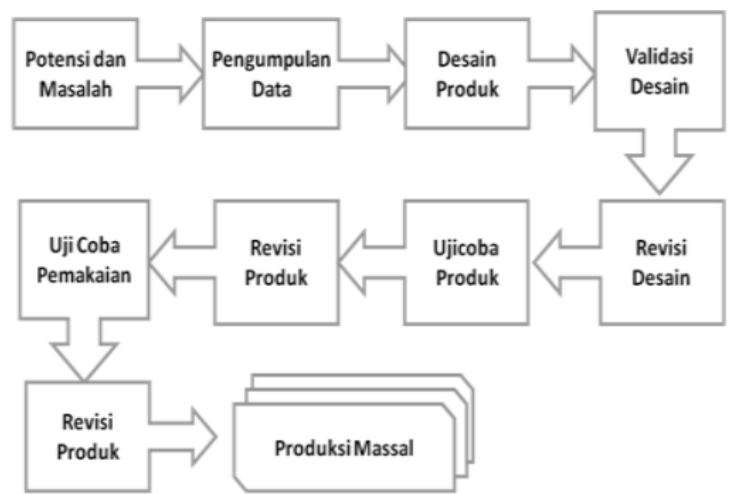

Gambar 1. Prosedur Penelitian Research and Development (Sugiyono 2009:409)

Prosedur pengembangan perangkat pembelajaran yang diadaptasi dalam penelitian ini menggunakan model ADDIE yang dikembangkan oleh Dick and Carry. Model pengembangan ADDIE terdiri dari lima tahap yaitu: Analysis, Design, Development, Implementation, dan Evaluation(McGriff, 2000). Model pengembangan ini dipilih berdasarkan atas pertimbangan bahwa model ini dikembangkan secara sistematis dan berpatokan pada landasan teoretis desain pembelajaran. Model ini disusun secara terprogram dengan urutan-urutan kegiatan yang sistematis dalam upaya pemecahan masalah belajar yang berkaitan dengan strategi penyampaian materi dan sesuai dengan kebutuhan serta karakteristik mahasiswa. Secara visual, tahapan model ADDIE dapat dilihat pada Gambar 2.

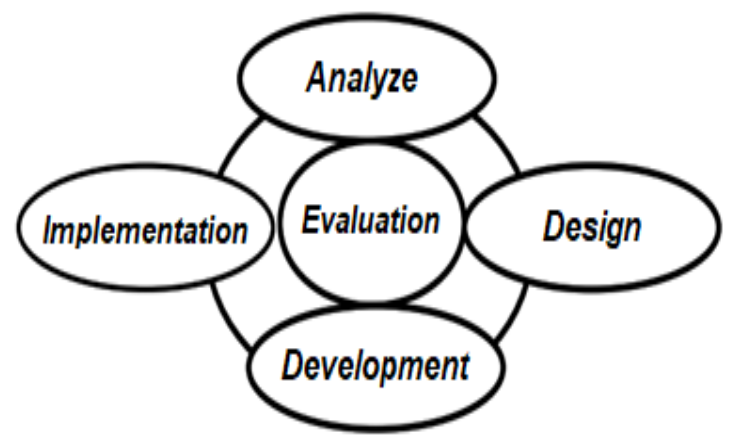

Gambar 2. Ilustrasi Model ADDIE (Dinatha and Kua, 2019)

Analisis awal atau identifikasi kebutuhan dilakukan untuk menetapkan masalah mendasar yang dihadapi dalam pelaksanaan praktikum
Teknik Digital. Analisis awal menghasilkan gambaran harapan, fakta yang terjadi, dan alternatif penyelesaian masalah dasar.

Hasil dari kegiatan analisis sebelumnya dijadikan sebabgai dasar untuk menentukan bagaimana modul praktikum Teknik Digital akan dirancang. Pada penelitian ini, modul praktikum Teknik Digital dengan menggunakan pendekatan Project Based Learning. Tujuan dari tahap perancangan ini yaitu untuk menyesuaikan produk yang akan dikembangkan dengan materi dan kompetensi yang akan dicapai mahasiswa.

Berdasarkan draft rancangan modul trainer yang diperoleh, maka dilanjutkan dengan tahap pengembangan. Tahap pengembangan merupakan proses utama dalam menghasilkan produk berupa modul praktikum Teknik Digital. Tahap ini didasarkan dari draft modul yang telah dirancang. Komponen dan rancangan rangkaian yang telah dirancang kemudian dirakit menjadi produk berupa modul praktikum.

Tahap selanjutnya adalah implementasi modul praktikum pada pelaksanaan perkuliahan praktikum Teknik Digital. Setelah mahasiswa melaksanakan praktikum dengan menggunakan modul yang dikembangkan, mahasiswa diminta untuk mengisi angket terkait kelayakan modul praktikum yang digunakan. Data angket mahasiswa dijadikan sebagai data primer untuk data penelitian. Data ini akan dijadikan sebagai umpan balik untuk revisi dan pengembangan modul selanjutnya.

Data yang diperoleh pada tahap Implementation dianalisis untuk melihat kesesuaian materi dan ketercapaian tujuan pengembangan modul praktikum. Hasil analisis data akan dijadikan topik pembahasan pada saat pelaksanaan Forum Group Discussion yang melibatkan dosen pengampu, kelompok dosen bidang keahlian dan ketua program studi. Kesimpulan dan kesepakatan dari FGD dijadikan acuan untuk melakukan revisi terhadap modul dan jobsheet praktikum yang dikembangkan.

Pengumpulan data pada penelitian ini dilakukan untuk menjaring informasi terkait kebermanfaatan modul dari segi media pembelajaran, materi dan pengguna. Pada penelitian ini, instrumen yang digunakan untuk pengumpulan data yaitu lembar penilaian untuk kelayakan produk yang dihasilkan. Instrumen 
diberikan kepada validator yang meliputi ahli materi dan ahli media. Instrumen juga diberikan kepada dosen dan mahasiswa untuk melihat respon pengguna.

Teknik analisis data yang digunakan yaitu teknik analisis data kualitatif. Data hasil penilaian dari validator dianalisis secara deskriptif kualitatif dan dijadikan sebagai acuan untuk revisi produk, sehingga menghasilkan produk yang layak digunakan. Hasil penilaian validator di ukur dengan Skala Likert. Skala likert beerisi beberapa pernyataan positif atau negative mengenai suatu obyek. Prinsip pokok skala likert adalah menentukan posisi kedudukan seseorang dalam menentukan sikap terhadap sikap suatu obyek(Wagiran, 2013). Penentuan kelayakan modul berdasarkan data hasil penilaian dari ahli materi, ahli media dan uji coba pengguna.

Tahapan langkah untuk melakukan analisis data yang diadaptasi dalam penelitian ini antara lain; 1) Mengubah penilaian dalam bentuk kualitatif menjadi kuantitatif; 2) Menghitung rata-rata skor; 3) Mengubah skor rata-rata menjadi nilai kualitatif; 4)Penentuan Kelayakan Modul.

\section{HASIL DAN PEMBAHASAN}

Penelitian menghasilkan modul praktikum teknik digital yang berisi 12 materi dan 20 percobaan. Modul ini sudah dilengkapi dengan materi dan petunjuk praktikum. Materi dan percobaan dikembangkan sesuai dengan kurikulum dan capaian pembelajaran.

Berdasarkan analsis yang dilakukan, diperoleh beberapa masalah yang dihadapi antara lain trainer kurang mendukung pelaksanaan praktikum dan petunjuk pelaksanaan praktikum belum lengkap. Dari analisis masalah yang diuraikan, dilakukan perancangan untuk mengatasi masalah tersebut. Perancangan modul praktikum Teknik Digital dilakukan dengan menggunakan pendekatan Project Based Learning. Desain modul praktikum berisi materi dan rangkaian percobaan Gerbang Logika, Rangkaian Digital, Flip-Flop, Encoder dan Decoder, Modulator Demodulator dan Seven Segment.

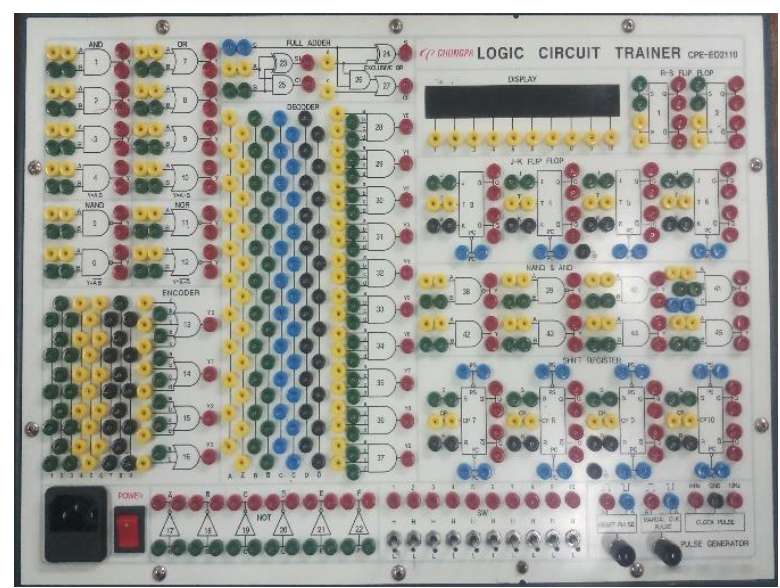

Gambar 3. Trainer Teknik Digital

Selanjutnya dilakukan pengembangan dari rancangan yang telah disusun. Pengembangan dilakukan untuk menentukan materi, perangkat pendukung dan petunjuk pelaksanaan praktikum. Hasil yang diperoleh dari tahap ini yaitu 20 percobaan yang dapat dilakukan dengan menggunakan trainer dan peralatan pendukung yang telah dirancang pada tahap sebelumnya. Kegiatan ini menghasilkan buku petunjuk praktikum Teknik Digital.

Tahap selanjutnya adalah Implementasi. Modul kemudian diimplementasikan pada kegiatan praktikum Teknik Digital. Mahasiswa melaksanakan kegiatan praktikum mengikuti petunjuk yang terdapat pada modul. Beberapa percobaan dilakukan berdasarkan materi dan jobsheet yang tersedia. Dosen mengarahkan mahasiswa dalam melaksanakan kegiatan praktikum Teknik Digital.

Tahap selanjutnya adalah evaluasi modul. Dua orang ahli materi dan dua orang ahli media ditunjuk sebagai validator. Selain itu, sepuluh orang mahasiswa diminta untuk memberikan penilaian terhadap kebermanfaatan produk. Sepuluh orang praktikan diberikan angket yang berisi penilaian berdasarkan pemanfaatan modul dalam kegiatan praktikum. Evaluasi dilakukan untuk memperoleh umpan balik dari pemanfaatan modul yang dikembangkan.

Hasil penilaian dari ahli media ditunjukkan pada gambar 4. 


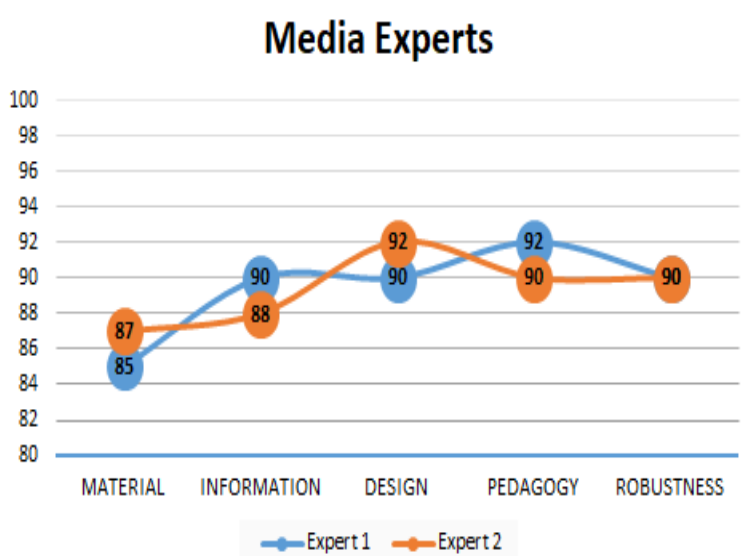

Gambar 4. Hasil penilaian ahli media

Hasil penilaian dari ahli materi ditunjukkan pada gambar 5 .

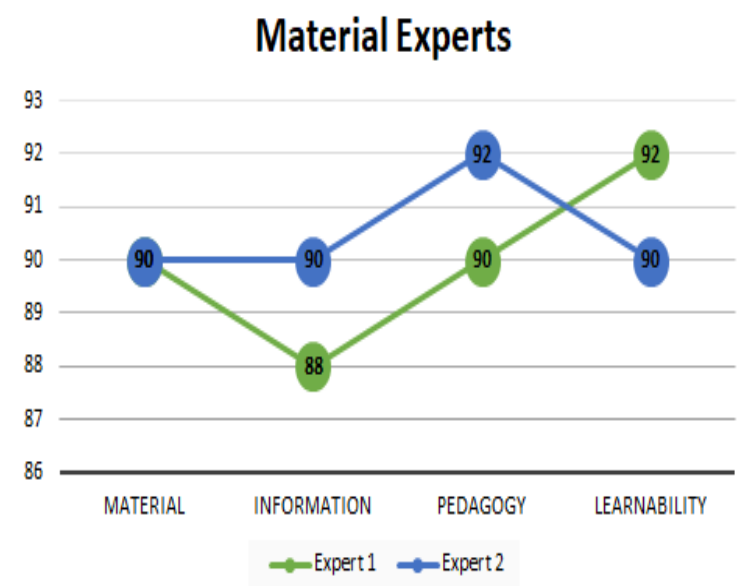

Gambar 5. Hasil penilaian ahli materi

Hasil penilaian dari uji coba pengguna ditunjukkan pada gambar 6.

Pengguna

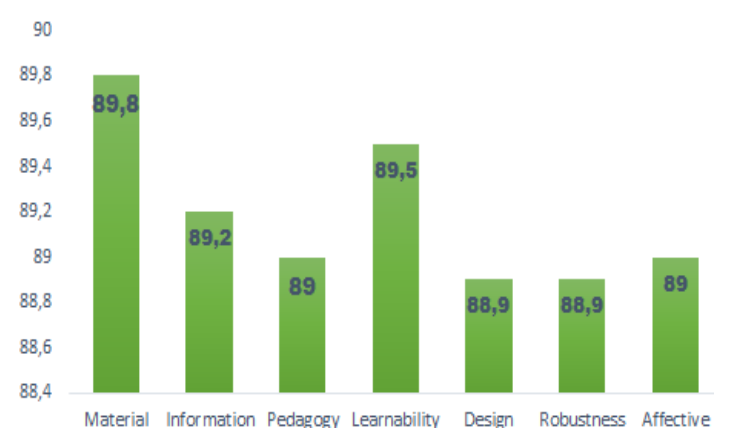

Gambar 6. Hasil ujicoba pengguna

Data hasil penilaian selanjutnya diubah menjadi nilai kualitatif. Berdasarkan nilai ratarata yang diperoleh selanjutnya dikonversi menjadi nilai kualitatif dalam bentuk kriteria. hasil penilaian dalam bentuk nilai kualitatif ditunjukkan pada tabel 4.
Tabel 1. Hasil penilaian kualitatif

\begin{tabular}{clll}
\hline No & Respondent & Score & Criteria \\
\hline $\mathbf{1}$ & Media Experts & 89,4 & Excellent \\
$\mathbf{2}$ & Material Experts & 90,3 & Excellent \\
$\mathbf{3}$ & Users & 89 & Excellent \\
\hline
\end{tabular}

Berdasarkan data penilaian dari ahli media, diperoleh rata-rata nilai 89,4. Nilai ini kemudian dijadikan acuan untuk menentukan kelayakan modul. Dari hasil perhitungan dan konversi nilai, dapat dikatakan bahwa modul praktikum yang dikembangkan berada dalam kategori sangat layak. Hasil ini menunjukkan bahwa modul praktikum dapat dimanfaatkan sebagai media dalam pembelajaran praktikum.

Penilaian ahli materi terdiri dari 4 aspek dengan nilai rata-rata 90,3. Uji kelayakan dilakukan untuk menentukan tingkat kelayakan materi yang terdapat di dalam modul praktikum. Berdasarkan perhitungan dan konversi nilai diperoleh hasil bahwa materi pada modul yang dikembangkan berada dalam kategori sangat layak. Hasil ini menunjukkan bahwa mmateri yang dikembangkan dalam modul praktikum sesuai dengan kurikulum dan kompetensi yang akan dicapai.

Uji coba terhadap pengguna juga dilakukan guna memperoleh umpan balik. Uji coba dilakukan kepada sepuluh orang mahasiswa yang terlibat dalam kegiatan praktikum Teknik Digital. Setiap mahasiswa diberi angket untuk menilai kelayakan modul yang dikembangkan dari sisi pengguna. Setelah dilakukan perhitungan rata-rata diperoleh nilai rata-rata uji coba pengguna adalah 89. Kemudian dilakukan perhitungan dan konversi untuk menentukan kelayakan modul dalam kegiatan praktikum. Hasil perhitungan menunjukkan bahwa modul yang dikembangkan berada dalam kondisi sangat layak.

Hasil penelitian menunjukkan bahwa modul praktikum yang dikembangkan sangat layak digunakan pada kegiatan praktikum Teknik Digital. Disamping itu, perlu pengembangan untuk sarana pendukung praktikum lainnya seperti trainer. Alat pendukung praktikum berupa gerbang logika yang memiliki 3 input dan 4 input belum tersedia. Sehingga ada beberapa percobaan yang belum dapat diselesaikan karena keterbatasan alat pendukung. 


\section{PENUTUP}

Penelitian ini berhasil mengembangkan modul praktikum Teknik Digital dengan menggunakan model ADDIE. Materi dan petunjuk percobaan sudah sesuai dengan kurikulum dan kompetensi yang akan dicapai. Modul yang dikembangkan sangat layak untuk digunakan sebagai pendukung kegiatan praktikum Teknik Digital berdasarkan hasil uji kelayakan. Setelah memanfaatkan modul ini, mahasiswa lebih memahami dan mampu menganalisis materi serta percobaan yang dilakukan pada kegiatan praktikum.

\section{DAFTAR PUSTAKA}

Degeng, I. N. . (2013) Ilmu pembelajaran: Klasifikasi variabel untuk pengembangan teori dan penelitian. Bandung: Kalam Hidup.

Dinatha, N. M. and Kua, M. Y. (2019) PENGEMBANGAN MODUL PRAKTIKUM DIGITAL BERBASIS NATURE OF SCIENCE ( NOS ) UNTUK MENINGKATKAN HIGHER ORDER THINKING SKILL ( HOTS )', 3, pp. 293 300 .

Fatkhurrohkhman, M. et al. (2017) 'Pengembangan Perangkat Pembelajaran Teknik Digital Berbasis Project Based Learning the Teaching Devices Development of Digital Engineering Using Project Based Learning in', 7(1), pp. 101-109.

Fry, H., Ketteridge, S., \& Marshall, S. (2014) A handbook for teaching and learning in higher education: Enhancing academic practice, 4th edition. 4th edn. London: Roudledge.

McGriff, S. . (2000) Instructional Systems. New York: College of Education, Penn State University. Available at: http://www.cdc.qc.ca/ actes_aqpc/2005/ellis_joanne_608.pdf,.

Mulyatiningsih, E. (2012) Metode penelitian terapan bidang pendidikan. Bandung: Alfabeta.

Parmin (2012) 'PENERAPAN CRITICAL REVIEW ARTIKEL PEMBELAJARAN IPA UNTUK MENINGKATKAN KEMAMPUAN MAHASISWA DALAM MENYUSUN PROPOSAL SKRIPSI', 1(2), pp. 183-191.
Suesthi Rahayuningsih, R. J. (2019) 'HIGH ORDER THINKING SKILLS (HOTS) MAHASISWA PROGRAM STUDI PENDIDIKAN MATEMATIKA DALAM MENYELESAIKAN MASALAH GRUP', 2(September), pp. 87-93.

Sugiyono (2009) Metode Penelitian Pendidikan. Bandung: Alfabeta Bandung.

Sugiyono (2014) Metode Penelitian Kuantitatif, Kualitatif dan $R \& D$. Bandung: Alfabeta.

Sugiyono, P. (n. d. ). D. (2017) Metode Penelitian Pendidikan: Pendekatan Kuantitatif, Kualitatif, $R \& D$. 25th edn. Bandung: CV Alfabeta.

Sumiati, S.; A. (2009) Metode Pembelajaran. Bandung: CV. Wacana Prima.

Wagiran (2013) Metodologi Penelitian Pendidikan (Teori dan Implementasi). Yogyakarta: Deepublish. 